Review Articles

\title{
Glucagon and Diabetes: A Reappraisal
}

\author{
P. J. Lefebvre and A. S. Luyckx ${ }^{1}$ \\ Division of Diabetes, Institute of Medicine, University of Liège, Belgium
}

Glucagon has often been at the centre of controversies. Discovered shortly after insulin [1], it has been neglected for many years by the vast majority of physiologists and clinicians with a few remarkable exceptions [2-6]. Its radioimmunoassay, described by Unger and his co-workers [7] shortly after the one reported by Yalow and Berson [8] for insulin, has been the major landmark in glucagon history. It has permitted the establishment of the basic principles of the physiology of the hormone [9]. In the following years, controversies abounded. Among them, let us recall that there has been a time when published values for plasma glucagon levels in man ranged from 100 to $8000 \mathrm{pg} / \mathrm{ml}$. Factors involved included crossreaction of some of the antisera used for the assay with material(s) originating from the gut (enteroglucagon or gut glucagon-like immunoreactivity) and incubation damage to the tracer leading to artefactually high readings of the unlabelled hormone. The paper by Sokal and Ezdinli in 1967 [10] reporting that, using a rat liver bioassay, plasma glucagon levels of a fasting normal man should be about $100 \mathrm{pg} / \mathrm{ml}$ helped much in clarifying an obscure situation. Another major controversy was raised by the observation by Samols et al. [11] that glucagon was a potent stimulator of insulin secretion, a finding in contrast with the views of that time on the physiological role of glucagon. This led to the interesting situation of having two chapters in the same monograph depicting virtually irreconcilable views on the physiology of the hormone $[12,13]$.

In 1979, the controversy on the role of glucagon in diabetes, raised by a paper published in 1975 by Unger and Orci [14], has stimulated numerous studies and fed (or even overfed) the columns of

1 Maître de Recherches of the F. N. R. S. of Belgium world-wide weekly medical periodicals with lettersto-the-Editor where facts, hypotheses and sometimes passionate interpretations were offered to the readers.

Having been involved for many years in glucagon research but having been dealing only partially with the role of glucagon in diabetes mellitus, we have attempted to give a cool look at this critically important question. A first difficulty lies in the fact that even definitions of glucagon and of diabetes are not easy to provide.

\section{What is Glucagon? What is Diabetes?}

The answer to the first question depends upon the responder. For the chemist, glucagon is a 29 aminoacid polypeptide with a molecular weight of 3485 ; its amino-acid sequence is known and subject to species variations. Recent X-ray analyses by the group of Blundell [15] have shown that the structure of glucagon in the crystals is largely helical with molecules associated in a complex arrangement of trimers, and have also provided evidence in favor of the existence of such helical trimers in the $\alpha$-granules of the islets of Langerhans and the formation of a helical conformer at the level of the glucagon receptor. In contrast with these precise chemical or physicochemical data, glucagon for the physiologist (or the clinician, some are both ...) is still a poorly characterized concept. It is accepted that glucagon is a circulating polypeptide hormone originating mainly but not exclusively from the A-cells of the islets of Langerhans; it is detected in plasma and tissues by radioimmunoassay: thus the term "immunoreactive glucagon" or IRG should be used. When a plasma or tissue extract is run on an appropriate chromatography column and then assayed using a so-called "specific" antiserum 
(such as the widely used antiserum $30 \mathrm{~K}$ available from Dr. R. H. Unger, Dallas), 3 to 4 fractions of different molecular weight are found; beside IRG $^{3500}$ which is probably related to what the chemist calls glucagon, a fraction of about 2000 daltons probably represents a degradation product, a fraction of about 9000 daltons might be a glucagon precursor and a fraction of about 200,000 daltons probably represents what Weir et al. [16] have called the "interference factor" or what Valverde et al. [17] have called "big plasma glucagon" or BPG. The physiological significance of this last compound is completely unknown. Glucagon originates essentially from the A cells of the islets of Langerhans of the pancreas. It has recently been shown that identical cells are present in the gastrointestinal tract, and indeed, a material which, according to all criteria, is identical to pancreatic glucagon has been extracted from the digestive tract of some animal species [18-20]. This "glucagon" is particularly abundant in the dog gastric fundus $[19,20]$ and, in the pig, is present not only in the gastric cardia but also in the duodenum, small intestine and colon $[21,22]$. The existence of such extrapancreatic "true glucagon" in man is still a matter of controversy (see below). Finally, a glucagon related peptide has also been found in the salivary glands of some species, mainly rodents [23].

To the question "What is diabetes?" asked by a Professor to one of his students, the latter answered "Sir, I did know, but I have forgotten!" The Professor then replied "It is a great shame since now nobody knows the answer". At the time of this Editorial and for operational purposes, we will consider diabetes as a frequent metabolic disorder existing in man and in many animal species, and characterized by hyperglycaemia, associated, in the more severe cases, by accelerated lipolysis and excessive ketogenesis.

\section{What Properties of Glucagon Make it a Candidate for Being Involved in the Pathogenesis of the Metabolic Disturbances of Diabetes Mellitus?}

Studies on isolated tissues and organs have shown that glucagon has the property of increasing mobilization of glucose, free fatty acids (FFA) and ketone bodies, metabolites which are found in excessive concentrations in the blood of diabetic patients.

Glucagon has no direct effect on peripheral glucose utilization [24]. It mobilizes glucose from the liver by three mechanisms: inhibition of glycogen synthesis, stimulation of glycogenolysis and enhancement of gluconeogenesis (see review in [25]). These effects on liver glucose output are effectively antagonized by insulin (review in [26]); and the effect is observed with concentrations of glucagon well within the physiological range (review in [26]). The lipolytic properties of glucagon are easy to demonstrate on isolated adipose tissue or fat cells from several animal species, mainly rodents; on human adipose tissue, particular experimental conditions are needed to observe glucagon-induced lipolysis; in all systems, insulin acts as a potent antagonist of glucagon-induced lipolysis (see reviews in [27, 28]). The enhancement of hepatic ketogenesis by glucagon is now a well accepted phenomenon; it is facilitated by a high amount of FFA, the substrate for ketogenesis, reaching the liver. As suggested by Mc Garry and his co-workers [29], fatty acid oxidation and ketogenesis are inhibited by malonyl CoA. In the presence of high concentrations of glucagon (and low concentrations of insulin), fatty acid synthesis in depressed, malonyl CoA levels are reduced, and, as a consequence, the carnitine acyltransferase system is activated, and fatty acid oxidation and ketogenesis are accelerated. Thus in isolated systems, glucagon induces metabolic changes similar to those observed in diabetes.

Experiments based on infusions of glucagon in normal animals or man do not help much in our understanding of the diabetogenic properties of glucagon: such infusions simultaneously release insulin, which, as we have seen, effectively antagonizes the effects of glucagon on liver glucose output, adipose tissue lipolysis and liver ketogenesis.

Critical experiments have been performed by infusing glucagon in animals or humans whose insulin secretion was inhibited by a simultaneous infusion of somatostatin or in insulin-deprived diabetic humans or animals.

Let us take, among many others, some examples:

1. In normal conscious dogs, infusion of somatostatin inhibited both insulin and glucagon secretion; an intraportal replacement infusion of glucagon stimulated both hepatic gluconeogenesis and hepatic glycogenolysis, the latter effect, however, being transient [30].

2. In somatostatin-infused, juvenile-onset, insulin-deficient diabetic subjects, intravenous infusion of small amounts of glucagon $(1 \mathrm{ng} / \mathrm{kg} / \mathrm{min})$ resulted in circulating hormone levels of approximately $200 \mathrm{pg} / \mathrm{ml}$; this caused a significant rise in plasma glucose, glycerol, FFA and 3-hydroxy-butyrate, all changes which were reversed by the simultaneous infusion of insulin [31].

3 . Glucagon ( $1 \mathrm{mg}$, subcutaneously) induced in diabetic patients a marked rise in blood glucose accompanied by a biphasic response of both acetoacetate and 3-hydroxybutyrate [32]. 
4. In juvenile-onset, insulin-deprived diabetic subjects, demonstrated to have no residual B-cell function, graded intravenous glucagon infusions resulted in a dose-related increase in blood glucose [33].

Thus various lines of evidence indicate that exogenous glucagon administration in insulin-deficient subjects aggravates the metabolic abnormalities of diabetes.

\section{Are Plasma Glucagon Levels Elevated in Diabetes?}

Plasma glucagon levels are usually markedly elevated in ketoacidosis [34, 35], hyperosmolar non-ketotic coma [36] and poorly controlled diabetes mellitus (review in [37]). In mild or moderate diabetes, plasma glucagon levels may be normal or moderately elevated (review in [37]); these values, however, are usually higher than the ones found in normal subjects made similarly hyperglycaemic ("relative hyperglucagonaemia"). Other abnormalities include: reduced inhibition of plasma glucagon levels by oral or intravenous glucose and even, sometimes, a paradoxical plasma glucagon rise after oral glucose; and exaggerated circulating glucagon levels in response to intravenous arginine infusion or to a large protein meal. All pertinent references can be found in two recent reviews [37, 38]. There is thus a general agreement that plasma glucagon levels are high (or relatively high) in diabetes mellitus, the highest values being recorded in the extreme situation represented by diabetic ketoacidosis.

\section{Does Endogenous Glucagon (in Absolute or Relative Excess) Play a Role in the Metabolic Abnormalities of Insulinopenic Diabetes?}

We have just seen: [1] that glucagon possesses in vitro and in vivo properties which qualify it as a potential diabetogenic hormone, and [2] that it is usually present in absolute or relative excess in diabetic patients. Nevertheless, the possible role of glucagon in mediating some of the metabolic abnormalities of diabetes remains controversial.

The first logical approach to this fundamental question was to see if diabetes, with all its metabolic features, can develop in the absence of glucagon. Until 1973, the dogma was that the A-cell of the islets of Langerhans was the only source of glucagon. At that time, three groups almost simultaneously reported [39-41] that glucagon was present in the plasma of insulin-deprived depancreatized dogs.
Soon after, it was demonstrated that the fundus of the dog stomach contains [18-20] and releases [18, 42-44] a material identical by all criteria to pancreatic glucagon; the dog stomach also possesses A-cells undistinguishable from the pancreatic A-cells [18]. Thus the pancreatectomized dog does not constitute a model of glucagon deficiency. Furthermore, when the hyperglucagonaemia of the pancreatectomized dog is inhibited by somatostatin, a dramatic fall in blood glucose is observed which parallels the fall in circulating extrapancreatic glucagon [45], thus demonstrating that extrapancreatic glucagon contributed to the hyperglycaemia of the depancreatized dog (which, since the experiment of von Mehring and Minkowski in 1889 was thought to be due solely to insulin deficiency).

The existence of an extrapancreatic source of glucagon in man remains disputed. Plasma glucagon measurements in pancreatectomized human subjects have yielded conflicting results: zero values were reported by Barnes*et al. [46], while other groups reported significant IRG levels in these patients (review in [47]), and even, a glucagon response to an arginine infusion [48]. In any case, a crucial experiment was reported in which the importance of glucagon in the development of diabetic hyperglycaemia and ketoacidosis was evaluated by withholding insulin from six patients with juvenile-type diabetes and four totally pancreatectomized subjects [49]. In juvenile-type diabetics, insulin withholding was associated with an abrupt rise in plasma glucagon and a sharp increase in blood glucose and plasma 3-hydroxybutyrate; in contrast, in pancreatectomized subjects, no significant rise in glucagon ${ }^{1}$ was observed, while a smaller but significant rise in blood glucose and plasma 3-hydroxybutyrate was obtained. This experiment demonstrates: [1] that glucagon is not "essential" for the development of hyperglycaemia and ketoacidosis, but also [2] that, in the presence of glucagon, both hyperglycaemia and ketoacidosis are enhanced and accelerated.

In a masterly series of experiments, Gerich and his co-workers (50) have reported findings which support a major role of glucagon in the metabolic abnormalities of diabetes. Insulin-dependent ketosisprone diabetics were made normoglycaemic by an

\footnotetext{
1 Plasma glucagon values reported in this paper are well below those usually reported in the literature. This is due to a glucagon immunoassay procedure in which each patient's plasma, stripped of glucagon by affinity chromatography, has been added to the tubes containing the glucagon standards. Unger has advocated [38] that some biologically active compounds, detected with conventional immunoassay could have escaped detection in the present procedure
} 
intravenous infusion of insulin. Terminating insulin infusion prompted a rapid rise in blood glucose, plasma FFA and 3-hydroxybutyrate which was paralleled by a rise in plasma glucagon. In contrast, if the glucagon rise was prevented by a somatostatin-infusion, the rise in blood glucose, plasma FFA and 3hydroxybutyrate was markedly reduced (but not completely prevented).

Similar results were reported by Alberti et al. [51] and Christensen et al. [52]. In this last study, somatostatin was infused for $24 \mathrm{~h}$ in juvenile diabetics; after the end of the infusion, plasma glucose rose abruptly, and so did plasma glucagon and plasma growth hormone, although less constantly. In this situation, $10 \mathrm{~h}$ after the last evening snack, the change in plasma glucose cannot be due to changes in intestinal absorption and is likely to be due to the changes in the hormones measured.

Recently, Raskin and Unger [53] reported, in four patients with juvenile-type diabetes treated with continuous insulin infusion, that a 48 hour-somatostatin-induced lowering of plasma glucagon was associated with an almost normalization of blood glucose and a marked reduction in glycosuria and ketonuria; restoring plasma glucagon levels by peripheral glucagon infusion (for a period of $48 \mathrm{~h}$; the somatostatin administration being maintained) resulted in restoration of the high blood glucose levels and reappearance of marked glycosuria. The conclusion that "hyperglucagonemia has an important role in diabetes" and that "its correction reduces diabetic abnormalities to or toward normal" was challenged by Sherwin and Felig [54] who advocated that the observations with somatostatin can largely be explained on the basis of interference with nutrient absorption and sensitization by somatostatin to the hyperglycemic effects of physiologic increments in glucagon. The objection was also raised that simultaneous suppression of growth hormone and perhaps that of other pituitary hormones by somatostatin may play a role in the final result [55].

Another objection against a major role of glucagon in the metabolic abnormalities of diabetes results from the findings of Clarke et al. [56] who demonstrated that elevating plasma glucagon concentrations to a range similar to those seen in poorly controlled diabetic subjects did not cause deterioration in blood glucose control or increased insulin requirements in diabetics being controlled with an artificial endocrine pancreas. Increased amounts of insulin were required only during maintenance of exceedingly high plasma glucagon concentrations. These observations should be analyzed in considering the role of insulin itself on glucagon secretion and effects (see below).
The likely role of glucagon in the control of liver ketogenesis has been supported by Boden et al. [7] who reported that, in a glucagonoma bearing patient, when plasma glucagon was $1800 \mathrm{pg} / \mathrm{ml}$, splanchnic ketone body production was four times greater than normal, but returned to normal values after removal of the tumor.

Thus, even if some interpretations are conflicting, most of the available data support the view that, in many circumstances, endogenous glucagon contributes to the hyperglycaemia and ketosis of diabetes even, if, in some rare instances, like total pancreatectomy, these metabolic abnormalities can develop despite undetectable levels of circulating glucagon.

\section{Insulin, Glucagon and Diabetes}

Space does not permit us to review here the numerous factors controlling glucagon release; the interested reader can consult one of the recent reviews on the subject $[58,59]$. Nevertheless, for our understanding of the role of glucagon in diabetes, one of the control mechanisms should be considered in some detail, namely the role exerted by insulin on glucose-mediated glucagon suppression.

Numerous observations support the concept that the A-cell belongs to the family of insulin sensitive cells (like muscle, the adipocyte or mammary gland) and that insulin is necessary for permitting glucose entry in the A-cell and subsequent inhibition of glucagon release. The normal pancreatic A-cell, in close contact inside the islets with B-cells, is in all probability usually exposed to high concentrations of insulin; therefore, its sensitivity to additional exogenous insulin may be difficult to demonstrate. In that respect, the A-cell of the canine gastric fundus represents an interesting model of an A-cell isolated in an organ devoid of B-cells; we have recently demonstrated that insulin concentrations as low as $5-10 \mu \mathrm{U} / \mathrm{ml}$ exert some inhibition of glucagon release from the canine gastric A-cell [60]. If one thus accepts the idea that insulin, when present, may permit glucose to inhibit glucagon secretion, many of the data reported on glucagon levels in diabetes can be interpreted with some rationale. Among these are:

1. The hypersuppressibility of plasma glucagon after oral glucose reported by Hatfield et al. [61] in the obese hyperinsulinaemic patients contrasting with the lack of suppressibility of the lean insulindeficient diabetic subjects.

2. The excessively high circulating levels of plasma glucagon despite extreme hyperglycaemia in diabetic ketoacidosis $[34,35]$. 
3. The prompt decrease in plasma IRG, as soon as insulin is given to these patients $[34,35]$.

4. The hypersuppressibility of plasma glucagon to oral [62] or intravenous [63] glucose in late pregnancy where hyperinsulinism is usually found.

Moving from the sites of production of insulin and glucagon to their sites of action, we must recall the antagonizing properties of insulin and glucagon on most of their target cells. If one thinks of the effects on the liver (glycogen synthesis, glycogenolysis, gluconeogenesis and ketogenesis), one should consider the relative concentrations of insulin and glucagon in the portal vein where, indeed, infusions and sampling in man are rarely possible for practical as well as ethical reasons. According to the "Bihormonal Abnormality" hypothesis of Unger and Orci [14], insulin deficiency would play the major role in decreasing peripheral glucose utilization and promoting adipose tissue lipolysis while glucagon excess (or relative excess) would be involved more in increased hepatic glucose production and liver ketogenesis. This view is challenged by Felig and his co-workers at Yale University [64-67] who advocate that the effect of glucagon on the liver is "transient" and wanes within 2-3h. Unger has recently developed at length his arguments in favor of the patho-physiological relevance of a transiently increased liver glucose output in face of a decreased or impaired glucose utilization due to impaired insulin secretion or effectiveness [38].

\section{Are the Abnormalities in Glucagon Secretion Cause or Consequences of Diabetes?}

We have just seen that insulin lack may explain some "non-suppressibility" or "excessive responsiveness" of the A cell. Therefore, the question naturally follows as to whether the abnormalities of glucagon secretion in diabetes may be a simple consequence of relative or absolute insulin deficiency. In insulindependent diabetics, insulin therapy usually normalizes the exaggerated glucagon response to amino acids [68, 69], reduces basal glucagon levels [68] but fails to fully correct the glucagon suppressive effect of glucose or does it only at supraphysiological concentrations $[70,71]$. The problem is that insulin is injected or infused peripherally so that the insular Acells "see" insulin levels which are probably far below those observed within the islets after glucoseinduced insulin secretion. Weir et al. [72] have emphasized the importance of these high intra-islet concentrations of insulin in glucose-induced glucagon suppression. Thus, in these patients, glucagon excess may result from insulin lack.
In maturity-onset type diabetics, abnormalities in glucagon secretion exist, despite the persistence of insulin: hyperresponse to arginine or protein ingestion and decreased suppressibility by glucose (review in [37]). The intimate mechanisms leading to these abnormalities are completely unknown. Among the hypotheses, beside an intrinsic perturbation of the glucagon releasing mechanisms, are a defect in intrainsular somatostatin [73] or a reduced sensitivity of the A-cells to insulin. This latter possibility, well accepted for various other cell types in these patients, has never been investigated.

\section{Should Glucagon Suppression be a Goal in Therapeutic Research?}

The data reviewed above leave little doubt that excessive plasma glucagon levels contribute to the metabolic abnormalities of diabetes.

In insulin dependent diabetic patients, insulin administration remains the corner-stone of management. The reasons for considering that glucagon suppression might be a useful adjunct to insulin therapy are as follows:

1. excessive plasma glucagon levels are usually found in patients receiving conventional insulin therapy:

2. glucagon abnormalities are not fully corrected even in patients treated by the "artificial pancreas" [74];

3. glucagon suppression by somatostatin improves diabetes control; control is worsened by glucagon replacement during somatostatin infusion [53].

Somatostatin itself is probably not the best candidate for chronic glucagon suppression: it affects the secretion of many other hormones, it reduces intestinal motility and may have some deleterious effects on platelet function.

Future pharmacological research should consider somatostatin analogues with selective glucagon-suppressing possibilities or agents suppressing glucagon by other mechanisms [75].

In that respect, the recent demonstration that prostaglandins stimulate glucagon release [76] and that prostaglandin-synthesis inhibitors reduce arginine- or noradrenaline-induced glucagon release [77] has opened new paths for future research. One should, however, consider that glucagon suppression may have undesirable consequences: it is now accepted that glucagon is "the first line of defense" against hypoglycaemia [78]; its suppression in patients receiving insulin may be dangerous. Thus, the ideal "pharmacologic profile" of a glucagon sup- 
pressor would be a compound inhibiting the hyperresponsiveness of the $A$ cell to various stimuli but preserving the acute response to hypoglycaemia ${ }^{2}$.

In maturity-onset type diabetics, somatostatin aggravates hyperglycaemia by its simultaneous inhibitory effect on insulin secretion [79]; it can therefore not be considered as a useful therapeutic adjunct. The effect of sulfonylureas and biguanides on A-cell function has led to conflicting results. Our group has observed that glipizide had no effect on plasma glucagon levels and that it preserved the glucagon response to hypoglycaemia, a fact considered as an advantage [80]. Here, the ideal pharmacologic suppressor would be a compound which [1] does not inhibit insulin secretion (contrary to somatostatin); [2] reduces the hyperresponsiveness to stimuli like aminoacids; but [3] preserves the response to hypoglycaemia (a useful safeguard if hypoglycaemic agents acting by other mechanisms, like the sulfonylureas, are simultaneously given).

\section{Conclusions}

The metabolic properties of glucagon, demonstrated both in vitro and in vivo, qualify it as a potential diabetogenic hormone. Plasma glucagon levels are usually elevated in diabetes, the highest levels being found in the absence of insulin. Numerous lines of evidence indicate that excess glucagon levels contribute to the metabolic abnormalities of diabetes. Nevertheless, diabetes can occur in the absence of glucagon (pancreatectomy in man). The absence of high intra-islet levels of insulin may explain the persistence of abnormally high plasma concentrations of glucagon in the diabetic receiving conventional insulin therapy. In maturity-onset type diabetes, the intimate mechanisms leading to abnormal circulating glucagon levels are completely unknown. A search for selective glucagon inhibitors represents an attractive new way in diabetes management.

Acknowledgement. We are indebted to E. Vaessen-Petit for expert secretarial assistance.

\section{References}

1. Murlin, J. R., Clough, H. D., Gibbs, C. B. F., Stokes, A. M.: Aqueous extracts of the pancreas. I. Influence on the carbohydrate metabolism of depancreatized animals. J. Biol. Chem. 56, 253-296 (1923)

2 Impaired glucagon response to hypoglycaemia has been reported in some diabetics [81] mainly those with autonomic neuropathy [82]. This abnormality has been said to contribute to diabetic instability
2. Stahl, J.: Recherches sur un principe hyperglycémiant d'origine pancréatique. Thèse Strasbourg, Librairie Universitaire d'Alsace 1931

3. Sutherland, E. W., De Duve, C.: Origin and distribution of the hyperglycemic-glycogenolytic factor of the pancreas. J. Biol. Chem. 175, 663-674 (1948)

4. Staub, A., Sinn, L., Behrens, O. K.: Purification and crystallization of hyperglycemic-glycogenolytic factor (HGF). Science 117, 628-629 (1953)

5. Foà, P. P., Galansino, G., Pozza, G.: Glucagon, a second pancreatic hormone, Recent Prog. Horm. Res. 13, 473-510 (1957)

6. Foà, P. P., Galansino, G.: Glucagon. Chemistry and function in health and disease, $126 \mathrm{pp}$. Springfield: C. C. Thomas 1962

7. Unger, R. H., Eisentraut, A.M., McCall, M.S., Madison, L. L.: Glucagon antibodies and an immunoassay for glucagon. J. Clin. Invest. 40, 1280-1289 (1961)

8. Yalow, R. S., Berson, S.: Assay of plasma insulin in human subjects by immunological methods. Nature 184, 1648-1649 (1959)

9. Unger, R. H., Eisentraut, A. M., McCall, M. S., Madison, L. L.: Measurements of endogenous glucagon in plasma and the influence of blood glucose concentration upon its secretion. J. Clin. Invest. 41, 682-689 (1962)

10. Sokal, J. E., Ezdinli, E. Z.: Basal plasma glucagon in man. J. Clin. Invest. 46, 778-785 (1967)

11. Samols, E., Marri, G., Marks, V.: Promotion of insulin secretion by glucagon. Lancet 1965 II, 415-417

12. Unger, R. H., Lefebvre, P. J.: Glucagon physiology. In: Glucagon. Molecular physiology, clinical and therapeutic implications. Lefebvre, P. J., Unger, R.H. (Eds.), pp. 213-244. Oxford: Pergamon Press 1972

13. Samols, E., Tyler, J. M., Marks, V.: Glucagon-insulin interrelationships. In: Glucagon. Molecular physiology, clinical and therapeutic implications. Lefebvre, P. J., Unger, R. H. (Eds.), pp. 151-173. Oxford: Pergamon Press 1972

14. Unger, R.H., Orci, L.: The essential role of glucagon in the pathogenesis of diabetes mellitus. Lancet 1975 II, 14-16

15. Sasaki, K., Dockerill, S., Adamiak, D., Tickle, I. J., Blundell, T.: X-ray analysis of glucagon and its relationship to receptor binding. Nature 257, 751-757 (1975)

16. Weir, G. C., Turner, R. C., Martin, D. B.: Glucagon radioimmunoassay using antiserum $30 \mathrm{~K}$. Interference by plasma. Horm. Metab. Res. 5, 241-244 (1973)

17. Valverde, I., Villanueva, M. L., Lozano, I., Marco, J.: Presence of glucagon immunoreactivity in the globulin fraction of human plasma ("Big plasma glucagon"). J. Clin. Endocrinol. Metab. 39, 1090-1098 (1974)

18. Sasaki, H., Rubalcava, B., Baetens, D., Blazquez, E., Srikant, C. B., Orci, L., Unger, R. H.: Identification of glucagon in the gastrointestinal tract. J. Clin. Invest. 56, 135-145 (1975)

19. Morita, S., Doi, K., Yip, C. C., Vranic, M.: Measurement and partial characterization of immunoreactive glucagon in gastrointestinal tissues of dogs. Diabetes 25, 1016-1025 (1976)

20. Srikant, C. B., McCorckle, K., Unger, R. H.: Properties of immunoreactive fractions of canine stomach and pancreas. J. Biol. Chem. 252, 1847-1851 (1977)

21. Holst, J. J.: Extraction, gel filtration pattern, and receptor binding of porcine glucagon-like immunoreactivity. Diabetologia 13, 159-169 (1977)

22. Larsson, L.-I., Holst, J. J., Håkanson, R., Sundler, F.: Distribution and properties of glucagon immunoreactivity in the digestive tract of various mammals: an immunohistochemical and immunochemical study. Histochemistry 44, 281-290 (1975)

23. Lawrence, A. M., Tan, S., Hojvat, S., Kirsteins, L.: Salivary gland hyperglycemic factor: an extra-pancreatic source of glucagon-like material. Science 195, 70-72 (1976) 
24. Lefebvre, P.: Le glucagon, seconde hormone pancréatique. Paris: Maloine 1967

25. Hers, H. G.: The control of glycogen metabolism in the liver. Annu. Rev. Biochem. 45, 167-188 (1976)

26. Park, C. R., Exton, J.H.: Glucagon and the metabolism of glucose. In: Glucagon. Molecular physiology, clinical and therapeutic implications. Lefebvre, P. J., Unger, R. H. (Eds.), pp. 77-108. Oxford: Pergamon Press 1972

27. Lefebvre, P. J.: Glucagon and lipid metabolism. In: Glucagon. Molecular physiology, clinical and therapeutic implications. Lefebvre, P. J., Unger, R.H. (Eds.), pp. 109-121. Oxford: Pergamon Press 1972

28. Lefebvre, P. J.: Glucagon and adipose tissue. Biochem. Pharmacol. 24, 1261-1266 (1975)

29. McGarry, J.D., Mannaerts, G.P., Foster, D. W.: A possible role for malonyl-CoA in the regulation of hepatic fatty acid oxidation and ketogenesis. J. Clin. Invest. 60, 265-270 (1977)

30. Cherrington, A.D., Lacy, W.W., Chiasson, J.L.: Effect of glucagon on glucose production during insulin deficiency in the dog. J. Clin. Invest. 62, 664-677 (1978)

31. Gerich, J. E., Lorenzi, M., Bier, D. M., Tsalikian, E., Schneider, V., Karam, J. H., Forsham, P. H.: Effect of physiologic levels of glucagon and growth hormone on human carbohydrate and lipid metabolism. J. Clin. Invest. 57, 875-884 (1976)

32. Simpson, R. W., Hockaday, T. D. R., Alberti, K. G. M. M.: Hormonal and metabolic responses to glucagon in diabetes mellitus. Clin. Endocrinol. (Oxf.) 7, 203-210 (1977)

33. Luyckx, A.S., Giugliano, D., Lefebvre, P. J.: Influence of exogenous glucagon on the metabolic abnormalities of insulin dependent diabetics. (Submitted for publication)

34. Assan, R., Hautecouverture, G., Guillemant, S., Dauchy, F., Protin, P., Derot, M.: Evolution de paramètres hormonaux (glucagon, cortisol et hormone somatotrope) et énergétiques (glucose, acides gras libres, glycerol) dans dix acidocétoses diabétiques graves traitées. Pathol. Biol. (Paris) 17, 1095-1105 (1969)

35. Müller, W., Faloona, G., Unger, R. H.: Hyperglucagonemia in diabetic ketoacidosis: its prevalence and significance. Am. J. Med. 54, 52-57 (1973)

36. Lindsey, C., Faloona, G., Unger, R. H.: Plasma glucagon in non-ketotic hyperosmolar coma. J.A.M.A. 229, 1771-1773 (1974)

37. Gerich, J.: On the causes and consequences of abnormal glucagon secretion in human diabetes mellitus. In: Glucagon: Its role in physiology and clinical medicine. Foà, P. P., Bajaj, J. S., Foà, N. L. (Eds.), pp. 617-641. New York, Heidelberg, Berlin: Springer 1977

38. Unger, R.H.: Role of glucagon in the pathogenesis of diabetes: the status of the controversy. Metabolism 27, 1691-1709 (1978)

39. Vranic, M., Pek, S., Kawamori, R.: Increased "glucagon immunoreactivity" in plasma of totally depancreatized dogs. Diabetes 23, 905-912 (1974)

40. Matsuyama, T., Foà, P. P.: Plasma glucose, insulin, pancreatic, and enteroglucagon levels in normal and depancreatized dogs. Proc. Soc. Exp. Biol. Med. 147, 97-102 (1974)

41. Mashiter, K., Harding, P. E., Chou, M., Mashiter, G. D., Stout, J., Diamond, D., Field, J. B. Persistent pancreatic glucagon but not insulin response to arginine in pancreatectomized dogs. Endocrinology 96, 678-693 (1975)

42. Lefebvre, P. J., Luyckx, A.S.: Factors controlling gastricglucagon release. J. Clin. Invest. 59, 716-722 (1977)

43. Blazquez, E. L., Muñoz-Barragan, L., Patton, G. S., Orci, L., Dobbs, R. E., Unger, R. H.: Gastric A-cell function in insulindeprived depancreatized dogs. Endocrinology 99, 1182-1188 (1976)
44. Blazquez, E., Muñoz-Barragan, L., Patton, G., Dobbs, R. E., Unger, R. H.: Demonstration of gastric glucagon hypersecretion in insulin-deprived alloxan diabetic dogs. J. Lab. Clin. Med. 89, 971-977 (1977)

45. Dobbs, R., Sakurai, H., Sasaki, H., Faloona, G., Valverde, I., Baetens, D., Orci, L., Unger, R. H.: Glucagon: role in the hyperglycemia of diabetes mellitus. Science 187, 544-546 (1975)

46. Barnes, A. J., Bloom, S. R., Mashiter, K., Alberti, K. G. M. M., Smythe, P., Turnell, D.: Persistent metabolic abnormalities in diabetes in the absence of glucagon. Diabetologia 13, 71-75 (1977)

47. Lefebvre, P., Luyckx, A.: Le glucagon extrapancréatique: données expérimentales et importance clinique. J. Annu. Diabétol. Hôtel-Dieu, 195-207. Paris: Flammarion 1978

48. Werner, P. L., Palmer, J. P.: Immunoreactive glucagon responses to oral glucose, insulin infusion and deprivation, and somatostatin in pancreatectomized man. Diabetes 27, 1005-1012 (1978)

49. Barnes, A. J., Bloom, S. R., Alberti, K. G. M. M., Smythe, P., Alford, A.P., Chisholm, D. J.: Ketoacidosis in pancreatectomized patients. N. Engl. J. Med. 296, 1250 (1977)

50. Gerich, J., Lorenzi, M., Bier, D., Schneider, V., Tsalikian, E., Karam, J., Forsham, P.: Prevention of human diabetic ketoacidosis by somatostatin: evidence for an essential role of glucagon. N. Engl. J. Med. 292, 985-989 (1975)

51. Alberti, K. G. M. M., Christensen, N. J., Iversen, J., Ørskov, H.: Role of glucagon and other hormones in the development of diabetic ketoacidosis. Lancet 1975 I, 1307-1311

52. Christensen, S. E., Hansen, Aa. P., Weeke, J., Lundbaek, K.: 24-hour studies of the effects of somatostatin on the levels of plasma growth hormone, glucagon, and glucose in normal subjects and juvenile diabetics. Diabetes 27, 300-306 (1978)

53. Raskin, P., Unger, R. H.: Hyperglucagonemia and its suppression: importance in the metabolic control of diabetes. N. Engl. J. Med. 299, 433-436 (1978)

54. Sherwin, R. S., Felig, P.: Hyperglucagonemia in diabetes (Letter). N. Engl. J. Med. 299, 1366-1367 (1978)

55. Barnes, A. J., Bloom, S. R., Alberti, K.G. M.M., Johnston, D. G.: Hyperglucagonemia in diabetes (Letter). N. Engl. J. Med. 299, 1367 (1978)

56. Clarke, W. L., Santiago, J. V., Kipnis, D.M.: The effect of hyperglucagonemia on blood glucose concentrations and on insulin requirements in insulin-requiring diabetes mellitus. Diabetes 27, 649-652 (1978)

57. Boden, G., Wilson, R.M., Owen, O. E.: Effects of chronic glucagon excess on hepatic metabolism. Diabetes 27, 643-648 (1978)

58. Gerich, J. E., Charles, M., Grodsky, G. M.: Regulation of pancreatic insulin and glucagon secretion. Annu. Rev. Physiol. 38, 353-388 (1976)

59. Lefebvre, P. J., Luyckx, A. S.: Factors controlling glucagon secretion. In: Regulatory mechanisms of carbohydrate metabolism. Essman, V. (Ed.), pp. 221-226. Oxford and New York: Pergamon Press 1978

60. Lefebvre, P. J., Luyckx, A. S.: Glucose and insulin in the regulation of glucagon release from the isolated perfused dog stomach. Endocrinology 103, 1579-1582 (1978)

61. Hatfield, H.H., Banasiak, M.F., Driscoll, T., Kim, H.-J., Kalkhoff, R. K.: Glucose suppression of glucagon: relationship to pancreatic beta cell function? J. Clin. Endocrinol. Metab. 44, 1080-1087 (1977)

62. Daniel, R. R., Metzger, B. E., Freinkel, N., Faloona, G. R., Unger, R. H., Nizan, M.: Carbohydrate metabolism in pregnancy. XI. Response of plasma glucagon to overnight fast and oral glucose during normal pregnancy and in diabetes. Diabetes $23,771-776$ (1974) 
63. Luyckx, A. S., Gerard, J., Gaspard, U., Lefebvre, P. J.: Plasma glucagon levels in normal women during pregnancy. Diabetologia 11, 549-554 (1975)

64. Felig, P., Wahren, J., Hendler, R.: Influence of physiologic hyperglucagonemia on basal and insulin-inhibited splanchnic glucose output in normal man. J. Clin. Invest. 58, 761-765 (1976)

65. Felig, P., Wahren, J., Sherwin, R., Hendler, R.: Insulin, glucagon and somatostatin in normal physiology and diabetes mellitus. Diabetes 25, 1091-1099 (1976)

66. Sherwin, R. S., Tamborlane, W., Hendler, R., Sacca, L., Defronzo, R. A., Felig, P.: Influence of glucagon replacement on the hyperglycemic and hyperketonemic response to prolonged somatostatin infusion in normal man. J. Clin. Endocrinol. Metab. 45, 1104-1107 (1977)

67. Sherwin, R., Fisher, M., Hendler, R., Felig, P.: Hyperglucagonemia and blood glucose regulation in normal, obese and diabetic subjects. N. Engl. J. Med. 294, 455-461 (1976)

68. Gerich, J.E., Tsalikian, E., Lorenzi, M., Schneider, V., Bohannon, N., Gustafson, G., Karam, J.: Normalization of fasting hyperglucagonemia and excessive glucagon responses to intravenous arginine in human diabetes mellitus by prolonged infusion of insulin. J. Clin. Endocrinol. Metab. 41, 1178-1180 (1975)

69. Raskin, P., Aydin, I., Unger, R. H.: The effect of insulin on the exaggerated glucagon response to arginine stimulation in diabetes mellitus. Diabetes 25, 227-229 (1976)

70. Aydin, I., Raskin, P., Unger, R. H.: The effect of short-term intravenous insulin administration on the glucagon response to a carbohydrate meal in adult-onset and juvenile-type diabetes. Diabetologia 13, 629-636 (1977)

71. Seino, Y., Ikeda, M., Kurahachi, H., Taminato, T., Sakurai, H., Goto, Y., Inoue, Y., Kadowaki, S., Kozaburo, M., Imura, H.: Failure to suppress plasma glucagon concentrations by orally administered glucose in diabetic patients after treatment. Diabetes 27, 1145-1150 (1978)

72. Weir, G. C., Knowlton, S. S., Atkins, R. F., McKennan, K., Martin, D. B.: Glucagon secretion from the perfused pancreas of streptozotocin-treated rats. Diabetes 25, 275-282 (1976)
73. Unger, R. H., Orci, L.: Hypothesis: the possible role of pancreatic D-cells in the normal and diabetic states. Diabetes $\mathbf{2 6}$, 241-244 (1977)

74. Kerner, W., Pfeiffer, E. F.: Glucagon secretion in diabetes during glucose-controlled insulin infusion. Diabetologia 13, 408 (1977)

75. Luyckx, A. S., Lefebvre, P. J.: Pharmacological compounds affecting plasma glucagon levels. Biochem. Pharmacol. 26, 2703-2708 (1976)

76. Pek, S., Tai, T. Y., Elster, A.: Stimulatory effects of prostaglandins $E_{1}, E_{2}$ and $F_{2}$-alpha on glucagon and insulin release in vitro. Diabetes 27, 801-809 (1978)

77. Luyckx, A.S., Lefebvre, P. J.: Possible role of endogenous prostaglandins in glucagon secretion by isolated guinea-pig islets. Diabetologia 15, 411--416 (1978)

78. Gerich, J. E.: Proc. 2nd Internat. Symposium on Hypoglycemia, Rome, January 1979. London, New York: Academic Press (in press)

79. Tamborlane, W. V., Sherwin, R. S., Hendler, R., Felig, P.: Metabolic effects of somatostatin in maturity-onset diabetes. N. Engl. J. Med. 297, 181-183 (1977)

80. Lecomte, M. J., Luyckx, A. S., Lefebvre, P. J.: Plasma glucagon and diabetes control in maturity-onset type diabetics. Respective effects of diet, placebo and glipizide. Diabète Metab. 3, 239-243 (1977)

81. Gerich, J.E., Langlois, M., Noacco, C., Karam, J.H., Forsham, P.: Lack of glucagon response to hypoglycemia in diabetes: evidence for an intrinsic pancreatic alpha cell defect. Science 182, 171-173 (1973)

82. Maher, T. D., Tanenberg, R. J., Greenberg, B. Z., Hoffman, J. E., Doe, R. P., Goetz, F. C.: Lack of glucagon response to hypoglycemia in diabetic autonomic neuropathy. Diabetes $\mathbf{2 6}$, 196-200 (1977)

Dr. P. J. Lefebvre

Division of Diabetes, Institute of Medicine

University of Liège

B-4020 Liège, Belgium 